\title{
Perubahan Perilaku Kelompok Bandeng C73 Melalui Pemanfaatan Tulang Ikan Bandeng (Chanos chanos) di Kecamatan Tirtajaya Karawang Jawa Barat
}

\author{
[Changes in C73 Milkfish Group Behavior Through Utilization of Milkfish Bones \\ (Chanos chanos) in Tirtajaya Karawang District, West Java]
}

\author{
Ena Hernawati, Lilis Supenti, Abdul Hanan \\ Program Studi Penyuluhan Perikanan, Politeknik Ahli Usaha Perikanan \\ Jalan Cikaret Nomor 2 Bogor 16132, Jawa Barat
}

\begin{abstract}
Abstrak
Penelitian ini bertujuan mempelajari perubahan perilaku Kelompok Bandeng C73 berupa pengetahuan, sikap dan keterampilan masyarakat tentang pemanfaatan tulang ikan bandeng melalui kegiatan penyuluhan. Penelitian dilakukan di Kecamatan Tirtajaya Kabupaten Karawang Provinsi Jawa Barat pada tanggal 2 Maret hingga 15 Mei 2020. Penyuluhan dilakukan menggunakan metode demonstrasi cara, ceramah dan diskusi. Aspek yang dievaluasi yaitu teknis, bisnis dan penyuluhan. Media yang digunakan dalam kegiatan penyuluhan yaitu media cetak berupa leaflet dan folder. Evaluasi penyuluhan dilakukan dengan membandingkan hasil pre test dan post test menggunakan kuesioner. Hasil penelitian menunjukkan bahwa perubahan perilaku masyarakat terhadap pemanfaatan limbah yaitu 76\%. dalam segi lingkungan sasaran bisa mengurangi dampak pencemaran lingkungan udara (bau), air (dibuang di irigasi), tanah (dibuang secara sembarangan). Hasil analisa ekonomi menunjukkan pemanfaatan limbah menguntung kan dalam satu kali produksi pembuatan tepung tulang menghasilkan keuntungan Rp.91.000.- dan jika tepung tersebut diolah kembali menjadi kerupuk tulang ikan, stik tulang ikan atau diversifikasi olahan lainnya maka akan menghasilkan keuntungan yang lebih tinggi. Pemanfaatan tulang ikan bandeng bukan hanya mengubah perilaku sasaran menjaga lingkungan tetapi juga memberi keuntungan dalam segi ekonomi.
\end{abstract}

Kata Kunci: hasil samping perikanan; nuget tuna; penyuluhan perikanan

\section{Abstract}

This study aims to increase public awareness of the importance of protecting the environment, increasing community knowledge, attitudes and skills regarding the utilization of milkfish bone waste. The research was conducted in Tirtajaya District, Karawang Regency, West Java Province on March 2 to May 15, 2020. This practice was carried out by means of demonstration methods, lectures and discussions. The aspects analyzed were technical, business and extension services. The media used in the extension activities were printed media + in the form of leaflets and folders and evaluation of the extension with the pre-test and post-test (questionnaire). The results showed that the change in gender behavior (society) towards the use of waste was $76 \%$. Utilization of milkfish bone waste not only changes target behavior but also provides benefits in terms of economy and environment. In terms of the environment, the target can reduce the impact of environmental pollution, air (smell), water (disposed of in irrigation), land (disposed of carelessly) this of course can affect public health. In terms of economics, the use of waste is quite profitable. In one production of bone meal, it generates a profit of Rp. 91,000. - and if the flour is reprocessed into calcium crackers, calcium sticks or other diversified preparations, it will produce higher profits.

Keywords: fishery by-products; fisheries extension; tuna nuggets 
Penulis Korespondensi

Ena Hernawati | enahrnwti21@gmail.com

\section{PENDAHULUAN}

Salah satu daerah yang memiliki potensi perikanan dan dikenal sebagai sentral perikanan di Provinsi Jawa Barat adalah Kabupaten Karawang. Kecamatan Tirtajaya, Kabupaten Karawang yang memiliki potensi perikanan tambak sebesar $2.382,19$ ha dan sentral aktivitas sektor perikanan. Kecamatan Tirtajaya memiliki 20 rumah tangga perikanan (RTP) bidang usaha pengolahan hasil perikanan. Usaha tersebut menggunakan bahan baku ikan bandeng. Terdapat dua kelompok pengolah yang membuat bandeng gepuk. Namun pengolahan ikan bandeng tersebut menjadi tidak ramah lingkungan karena membuang hasil sampingnya di saluran air dan lahan yang kosong. Bahan baku yang digunakan kelompok dalam satu kali produksi yaitu $60 \mathrm{~kg}$ ikan bandeng. Prosentase hasil samping yang terbuang sekitar 20\%. Hasil samping yang terbuang dalam satu kali produksi yaitu $12 \mathrm{~kg}$. Hasil samping usaha pengolahan bandeng gepuk adalah tulang ikan bandeng. Tulang ikan bandeng bisa di manfaatkan sebagai tepung ikan dan tepung tulang ikan bisa dijadikan bahan untuk pembuatan pakan ikan selain itu dapat dijadikan sebagai bahan dasar pembuatan olahan kering hasil perikanan (Hernawati 2019).

Hasil samping usaha perikanan masih mengandung zat gizi seperti protein, lemak dan mineral (Prayudi et al. 2020). Pemanfaatan hasil samping perikanan diharapkan dapat memanfaatkan zat gizi tersebut untuk olahan ikan yang inovatif. Kerupuk tulang ikan adalah olahan yang ditambah dengan tepung tulang ikan. Penambahan tepung tulang ikan dapat meningkatkan kadar kalsium dan tingkat kesukaan konsumen (Sumbodo, Amalia, dan Purnamayati 2019). Pemanfaatan tulang ikan untuk membuat olahan lain dari bahan baku bandeng, secara ekonomi juga dapat meningkatkan keuntungan para pengolah. Diversifikasi olahan ikan beberapa jenis olahan, menggunakan bahan baku ikan yang sama lebih menguntungkan dibandingkan dengan membuat satu produk olahan ikan (Amdar, Anas, dan Yuniarti 2019).

Pengolah dapat meningkatkan kapasitas dirinya melalui berbagai cara. Peningkatan kapasitas diri melalui peningkatan pengetahuan, sikap dan keterampilan cara membuat inovasi produk olahan ikan dapat dilakukan dengan mengikuti kegiatan penyuluhan. Penyuluhan yang merupakan proses 
atau wadah pembelajaran bagi pelaku utama maupun pelaku usaha perikanan tidak terlepas dari media yang berkaitan dengan teknologi. Media berperan penting dalam penyampaian inovasi mengenai teknologi dalam bidang perikanan (Mardikanto 2009). Tujuan penelitian adalah mempelajari perubahan pengetahuan, sikap dan keterampilan pengolah ikan bandeng pada Kelompok Bandeng C73 melalui penyuluhan pemanfaatan tepung tulang ikan bandeng sebagai bahan pembuatan kerupuk tulang bandeng.

\section{BAHAN DAN METODE}

Penelitian dilaksanakan pada tanggal 02 Maret 2020 sampai 15 Mei 2020 Kecamatan Tirtajaya Kabupaten Karawang Provinsi Jawa Barat. Lokasi dalam pelaksanaan penelitian adalah di Kecamatan Tirtajaya tepatnya Desa Tambaksari, Lokasi tersebut dipilih karena merupakan pusat perikanan dan pembuangan tulang ikan bandeng. Sasaran penyuluhan adalah Kelompok Bandeng C73 dengan jumlah anggota 10 orang.

Data pendukung berupa sumber daya alam dan sumber daya manusia diperoleh dari Biro Pusat Statistik (BPS), Kantor Dinas Perikanan Kabupaten Karawang, Rencana Kerja Penyuluh Perikanan. Materi penyuluhan adalah pemanfaatan tulang ikan bandeng untuk membuat tepung tulang ikan dan diversifikasi olahan dari tepung tulang ikan berupa kerupuk tulang ikan. Penyuluhan mengenai pembuatan tepung tulang ikan bandeng dilaksanakan pada tanggal 16 Maret 2020 di rumah produksi kelompok Bandeng C73. Penyuluhan mengenai diversifikasi olahan dari tepung tulang ikan yaitu kerupuk tulang ikan bandeng dilakukan pada tanggal 5 April 2020 bertempat di rumah produksi kelompok Bandeng C73.

Pembuatan tulang ikan bandeng menggunakan metode Putra and Anna (2017) yang dimodifikasi pada bagian pengeringannya. Prosedur pembuatan tepung tulang iak bandeng yaitu mencuci tulang ikan bandeng, mengukus selama 30 menit. Selanjutnya tulang ikan di cuci kembali untuk membuang sisa daging ikan. Pengeringan dilakukan selama 2-3 hari menggunakan bantuan sinar matahari. Tulang ikan yang sudah kering, digiling hingga halus. Terakhir, dilakukan pengayakan agar tepung tuang halus homogen.

Pembuatan kerupuk tulang ikan bandeng sesuai dengan metode Putra and Anna (2017). Bahan yang digunakan adalah tepung tulang ikan bandeng 5\% dari tepung tapioka, bumbu bawang putih, ketumbar, merica dan garam. Prosedur pembuatan kerupuk tulang ikan adalah mencampur bahan berupa 
tepung tulang ikan, tepung tapioka dan bumbu dengan air panas, lalu diaduk hingga kalis. Adonan dibungkus dengan daun pisang, kemudian dikukus selama 2 jam. Adonan yang telah matang, didinginkan selama 24 jam, kemudian diiris-iris kurang lebih ketebalan $2 \mathrm{~mm}$. Kerupuk mentah dijemur selama 1-2 hari di bawah sinar matahari. Kerupuk mentah dapat dikemas atau digoreng matang untuk dijual.

Evaluasi awal untuk mengetahui tingkat pengetahuan dan sikap dilakukan sebelum dilakukan penyuluhan. Metode penyuluhan adalah demonstrasi cara. Sosialisasi secara partisipatif dilakukan sehingga sasaran dapat aktif mengikuti kegiatan penyuluhan. Diskusi dilakukan setelah demonstrasi cara dan sosialisasi mengenai materi kegiatan selesai dan ditutup dengan evaluasi akhir untuk mengetahui sejauh mana peningkatan pengetahuan, sikap dan keterampilan sasaran terhadap penyuluhan yang disampaikan.

Evaluasi dilakukan sebelum pelaksanaan penyuluhan (pre-test) dan sesudah pelaksanaan penyuluhan (posttest) dengan cara melakukan pengisian kuisioner. Kuisioner yang diberikan terdiri dari tiga aspek yaitu aspek pengetahuan, sikap dan keterampilan. Hasil evaluasi dihitung nilai perubahan yaitu denga cara mencari selisih dari kegiatan evaluasi awal dan evaluasi akhir sehingga diperoleh nilai perubahan. Analisis data menggunakan SPSS sederhana untuk mengetahui perubahan pelaksanaan penyuluhan terhadap perubahan tingkat pengetahuan, keterampilan dan sikap sasaran.

Kriteria skor dalam evaluasi aspek pengetahuan adalah setiap soal yang diberikan jika benar maka skor: 1, sedangkan jika jawaban responden salah maka skor : 0 . Skor pada evaluasi aspek sikap adalah 5 = sangat setuju, 4 = setuju, 3 = ragu-ragu, 2 = tidak setuju dan 1 = sangat tidak setuju.

\section{HASIL DAN PEMBAHASAN}

\section{Hasil}

Sasaran penyuluhan adalah anggota kelompok bandeng C73 sejumlah 10 orang. Karakteristik sasaran perlu diketahui sebelum melakukan penyuluhan. Karakteristik sasaran pada penelitian ini adalah usia sasaran, tingkat 
Tabel 1. Hubungan Usia, Tingkat Pendidikan dan Pengalaman Usaha Sasaran

\begin{tabular}{l|c|c|c|c|c|cc|c}
\hline & Usia & \multicolumn{3}{c|}{ Tingkat Pendidikan } & \multicolumn{3}{c}{ Pengalaman Usaha } \\
\hline Kategori & $\begin{array}{c}\text { Standar } \\
\text { (Tahun) }\end{array}$ & $\begin{array}{c}\text { Jumlah } \\
\text { (Orang) }\end{array}$ & Kategori & $\begin{array}{c}\text { Standar (Pend. } \\
\text { Formal) }\end{array}$ & $\begin{array}{c}\text { Jumlah } \\
\text { (Orang) }\end{array}$ & Kategori & $\begin{array}{c}\text { Standar } \\
\text { (Tahun) }\end{array}$ & $\begin{array}{c}\text { Jumlah } \\
\text { (Orang) }\end{array}$ \\
\hline luda & $\leq 31$ & 2 & Rendah & TS & 2 & Baru & $\leq 4$ & 3 \\
edang & $31>X \leq 48$ & 7 & Sedang & SD & 5 & Sedang & $4>X \leq 8$ & 4 \\
ua & $>48$ & 1 & Tinggi & SMP & 3 & Lama & $>8$ & 3 \\
\hline \multicolumn{2}{c}{ Jumlah Sasaran } & $: 10$ & \multicolumn{2}{c}{ Jumlah Sasaran } & $: 10$ & Jumlah Sasaran & $: 10$ \\
\hline
\end{tabular}

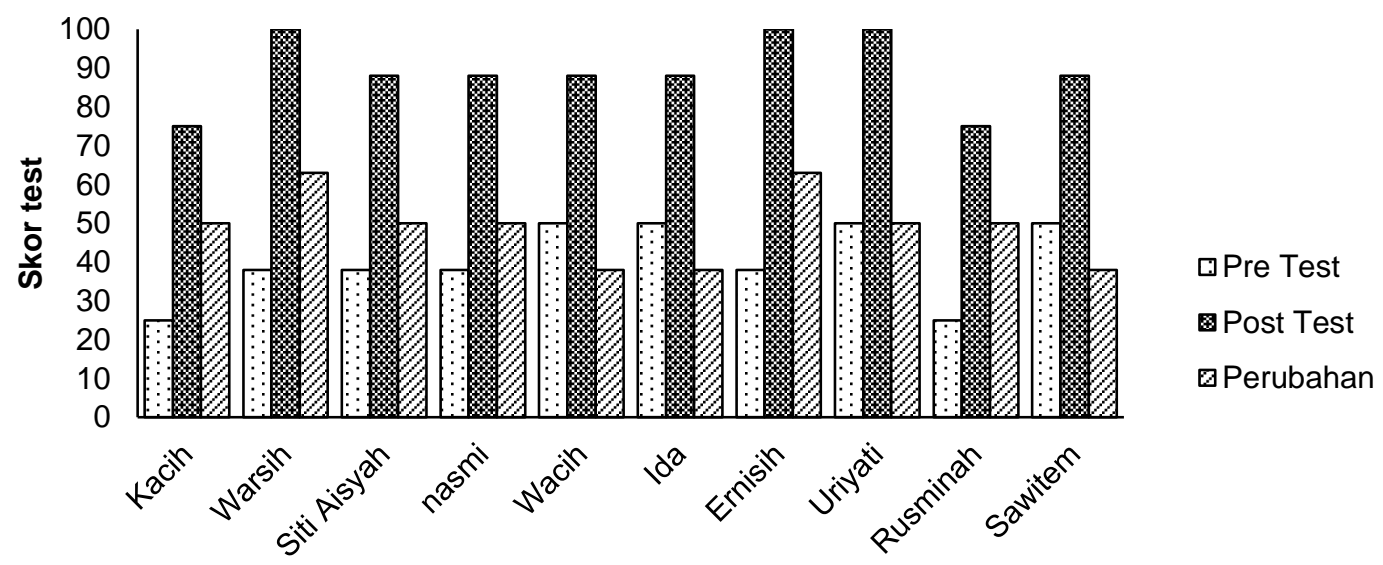

Nama sasaran penyuluhan

Gambar 1. Hasil Pre-test dan Post-test aspek pengetahuan sasaran penyuluhan terhadap meteri pembuatan tulang ikan bandeng

pendidikan, dan pengalaman usaha dapat dilihat pada Tabel 1.

\section{Penyuluhan Mengenai Pemanfaatan Tulang Ikan}

Penyuluhan

mengenai

pemanfaatan tulang ikan bertujuan untuk meningkatkan pengetahuan, sikap maupun keterampilan sasaran dalam pemanfaatan tulang ikan yaitu pembuatan tepung tulang ikan. Materi yang diberikan ditekankan pada: (1) cara membersihkan tulang dari bagian kotoran perut, (2) cara mencuci tulang, (3) menerapkan cara produksi yang baik dengan menerapkan kebersihan alat, bahan dan diri, (4) prosedur pembuatan tepung tulang ikan. Evaluasi hasil penyuluhan dilakukan dengan menggunakan kuisioner yaitu pada saat sebelum menerima penyuluhan (pretest) dan sesudah menerima penyuluhan (post-test) terhadap tingkat pengetahuan dan sikap sasaran. Hasil pre-test dan post-test disajikan pada Gambar 1.

Hasil evaluasi perubahan aspek sikap responden setelah menerima materi penyuluhan berupa pembuatan tepung tulang ikan bandeng dapat dilihat pada Tabel 2. 
Tabel 2. Hasil Post test dan Pre test aspek sikap

\begin{tabular}{|c|c|c|c|c|c|c|c|c|c|c|c|c|}
\hline \multirow{3}{*}{ NO } & \multicolumn{5}{|c|}{ PRE TEST } & \multirow{3}{*}{ Jumlah } & \multicolumn{5}{|c|}{ POST TEST } & \multirow{3}{*}{ Jumlah } \\
\hline & ss & $\mathbf{S}$ & $\mathbf{R}$ & TS & STS & & SS & $\mathbf{S}$ & $\mathbf{R}$ & TS & STS & \\
\hline & 5 & 4 & 3 & 2 & & & 5 & 4 & 3 & 2 & & \\
\hline 1 & & 2 & 3 & 5 & & 10 & 6 & 3 & 1 & 0 & & 10 \\
\hline 2 & & 2 & 4 & 4 & & 10 & 4 & 4 & 2 & 0 & & 10 \\
\hline 3 & & 0 & 5 & 3 & & 10 & 6 & 2 & 2 & 0 & & 10 \\
\hline 4 & & 2 & 5 & 5 & & 10 & 5 & 3 & 2 & 0 & & 10 \\
\hline 5 & & 2 & 5 & 3 & & 10 & 4 & 4 & 2 & & & \\
\hline Jumlah & & 8 & 22 & 20 & & & 25 & 16 & 9 & 0 & & \\
\hline Rata-Rata & & 1.6 & 4.4 & 4 & & & 5 & 3.2 & 1.8 & 0 & & \\
\hline
\end{tabular}

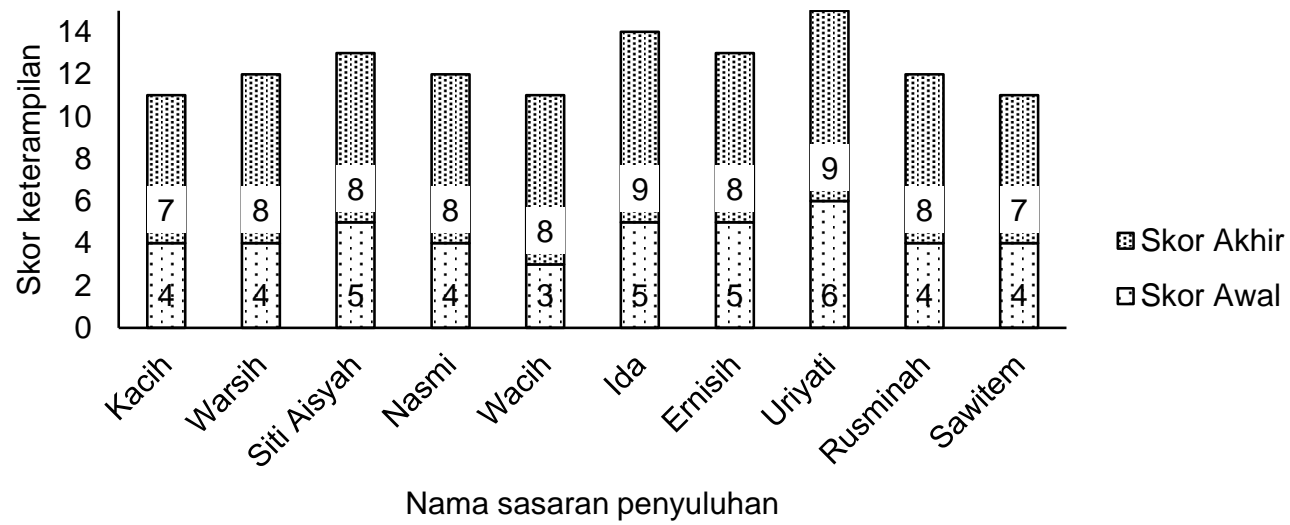

Gambar 2. Hasil Post test dan Pre test Aspek Keterampilan

Tingkat perubahan aspek keterampilan sasaran sebelum dan sesudah menerima materi penyuluhan pembuatan tepung tulang ikan disajikan pada Gambar 2.

Evaluasi adopsi inovasi dilakukan dengan cara mengamati tingkat penerimaan dan penerapan sasaran terhadap materi atau inovasi yang telah disampaikan mengenai pembuatan tepung tulang ikan bandeng. Data adopsi inovasi sasaran terhadap penyuluhan demonstrasi cara pembuatan tepung tulang ikan disajikan pada Gambar 3.

Evaluasi yang terakhir adalah evaluasi difusi dengan mengukur sudah sejauh mana sasaran yang diberikan penyuluhan menyalurkan informasi yang diberikan. Evaluasi yang dilakukan penyaluran dapat dilihat pada Tabel 3.

\section{Penyuluhan Demonstrasi Cara Pembuatan Kerupuk Tulang Ikan Bandeng}

Penyuluhan mengenai pembuatan kerupuk tulang ikan bandeng 


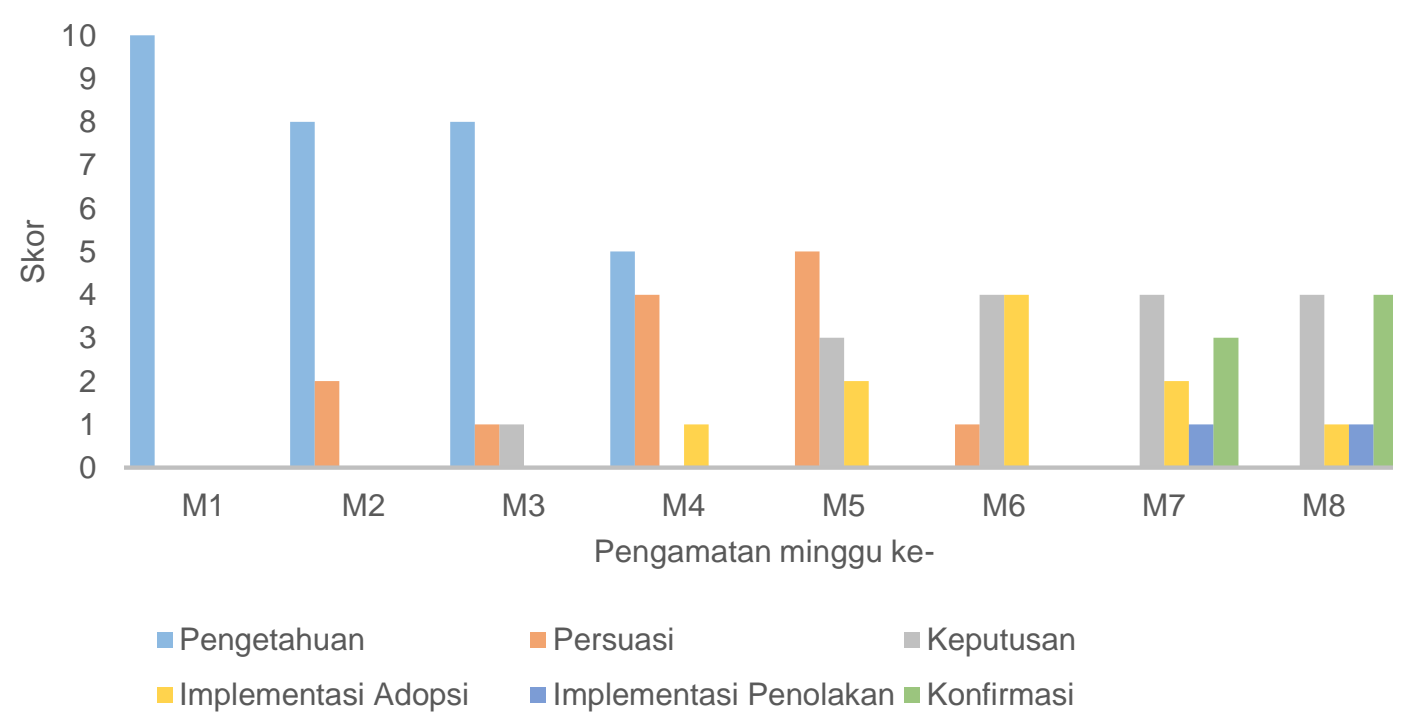

Gambar 3. Adopsi inovasi terhadap penyuluhan demonstrasi cara pembuatan tepung tulang ikan

Tabel 3. Difusi Pembuatan Tepung Tulang Ikan

\begin{tabular}{llc}
\hline No & Nama Sasaran & Jumlah Difusi (Orang) \\
\hline 1 & Kacih & 2 \\
2 & Warsih & 3 \\
3 & Siti Asiyah & 1 \\
4 & Nasmi & 0 \\
5 & Wacih & 0 \\
6 & Ida & 2 \\
7 & Ermisih & 2 \\
8 & Uriyati & 15 \\
9 & Rumsinah & 2 \\
10 & Sawitem & 0 \\
\hline Jumlah & 27 \\
\hline
\end{tabular}

dilaksanakan pada Kelompok Bandeng C73. Kegiatan ini bertujuan untuk meningkatkan pengetahuan, sikap maupun keterampilan sasaran dalam pembuatan kerupuk tulang. Materi yang diberikan ditekankan pada: penakaran bahan baku, (2) menerapkan cara produksi yang baik dengan menerapkan kebersihan alat, bahan dan diri, (3) prosedur pembuatan tepung tulang ikan. Kegiatan aksi penyuluhan diawali dengan pre-test, pemberian materi penyuluhan dan post-test. Hasil pre-test dan post-test pada aspek 


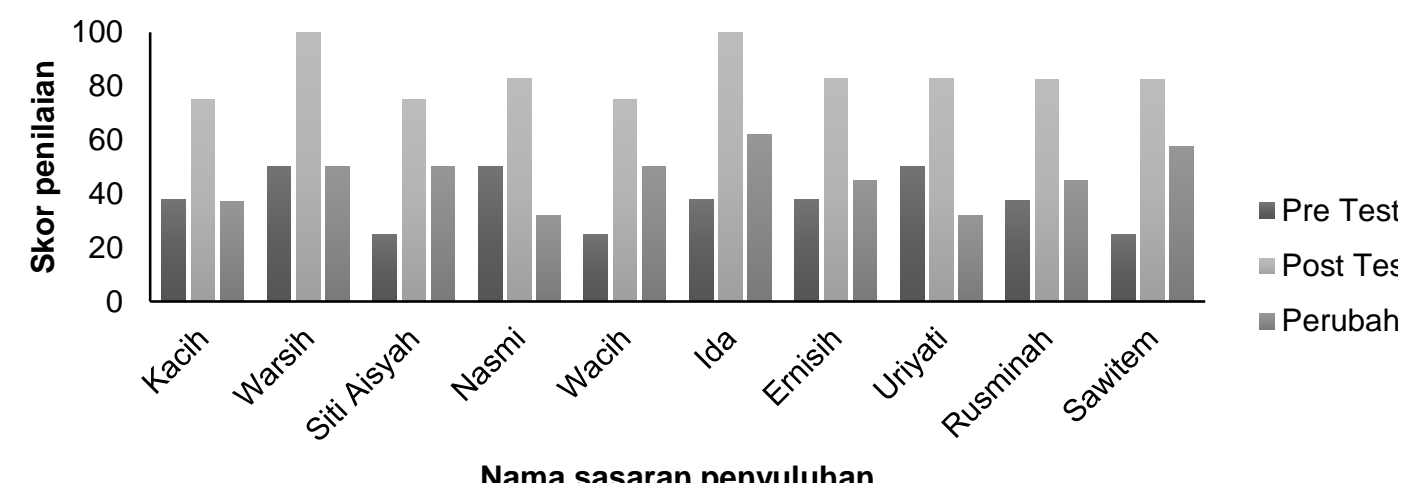

Gambar 4. Hasil Pre-test dan Post-test Aspek Pengetahuan

Tabel 4. Hasil Post test dan Pre test Aspek Sikap

\begin{tabular}{|c|c|c|c|c|c|c|c|c|c|c|c|c|}
\hline \multirow{3}{*}{ NO } & \multicolumn{5}{|c|}{ PRE TEST } & \multirow{3}{*}{ Jumlah } & \multicolumn{5}{|c|}{ POST TEST } & \multirow{3}{*}{ Jumlah } \\
\hline & SS & $S$ & $\mathbf{R}$ & TS & STS & & SS & $\mathbf{S}$ & $\mathbf{R}$ & TS & STS & \\
\hline & 5 & 4 & 3 & 2 & 1 & & 5 & 4 & 3 & 2 & & \\
\hline 1 & & 2 & 4 & 4 & & 10 & 6 & 4 & & & & 10 \\
\hline 2 & & 3 & 4 & 3 & & 10 & 8 & 2 & & & & 10 \\
\hline 3 & & 1 & 5 & 4 & & 10 & 5 & 5 & & & & 10 \\
\hline 4 & & 3 & 5 & 2 & & 10 & 4 & 6 & & & & 10 \\
\hline 5 & & 2 & 6 & 2 & & 10 & 4 & 6 & & & & 10 \\
\hline Jumlah & & 11 & 24 & 15 & & & 27 & 23 & & & & \\
\hline Rata-Rata & & 2.2 & 4.8 & 3 & & & 5.4 & 4.6 & & & & \\
\hline
\end{tabular}

pengetahuan sasaran mengenai pembuatan kerupuk tulang ikan bandeng disajikan pada Gambar 4.

Hasil evaluasi aspek keterampilan sasaran penyuluhan dengan materi pembuatan kerupuk tulang ikan bandeng disajikan pada Gambar 5.

Evaluasi adopsi inovasi tingkat penerimaan dan penerapan sasaran terhadap materi atau inovasi yang telah disampaikan mengenai penerapan pembuatan kerupuk tulang ikan bandeng, disajikan pada Gambar 6 .
Evaluasi yang terakhir adalah evaluasi difusi dengan mengukur sudah sejauh mana sasaran yang diberikan penyuluhan menyalurkan informasi yang diberikan. Evaluasi yang dilakukan penyaluran dapat dilihat pada Tabel 5 . 


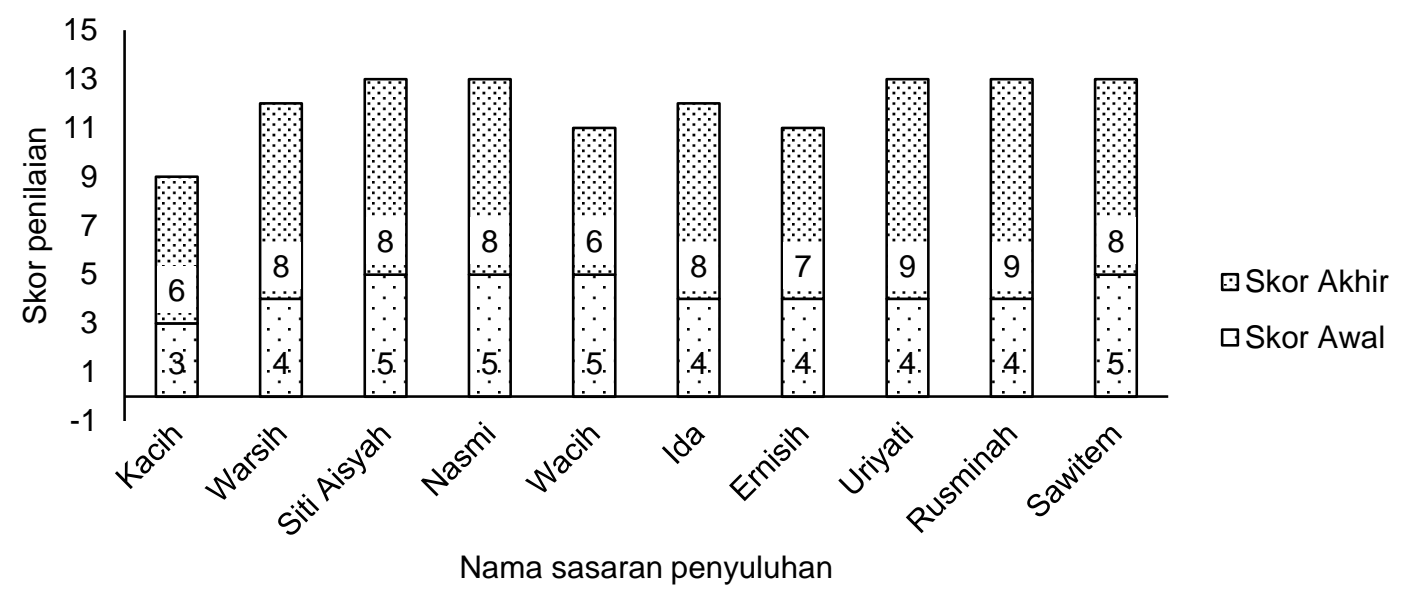

Gambar 5. Hasil Post test dan Pre test Aspek Keterampilan

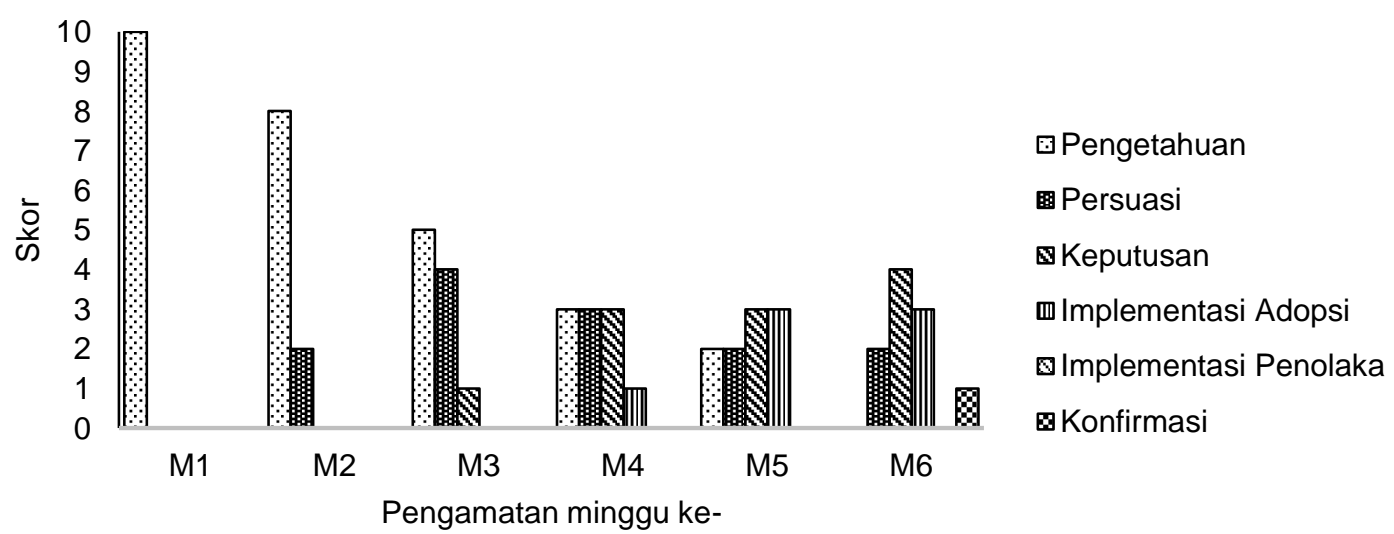

Gambar 6. Adopsi inovasi terhadap penyuluhan demonstrasi cara pembuatan tepung tulang ikan 
Tabel 5. Difusi Pembuatan Kerupuk Tulang ikan

\begin{tabular}{llc}
\hline No & Nama Sasaran & Jumlah Difusi (Orang) \\
\hline 1 & Kacih & 5 \\
2 & Warsih & 4 \\
3 & Siti Asiyah & 2 \\
4 & Nasmi & 0 \\
5 & Wacih & 0 \\
6 & Ida & 2 \\
7 & Ermisih & 1 \\
8 & Uriyati & 10 \\
9 & Rumsinah & 2 \\
10 & Sawitem & 3 \\
\hline \multicolumn{3}{c}{ Jumlah }
\end{tabular}

\section{Pembahasan}

Upaya yang sering dilakukan, agar inovasi teknologi cepat sampai pada anggota jaringan, adalah melakukan pertemuan tatap muka dan kunjungan, media penyuluhan yang paling disukai anggota jaringan komunitas untuk transfer inovasi teknologi adalah media televise, serta brosur/buku saku dan metode penyuluhan yang dinilai paling efektif adalah sekolah lapang, temu lapang dan demplot/demonstrasi cara (Purnomo et al. 2015).

Pemilihan metode penyuluhan dipengaruhi oleh karakteristik sasaran penyuluhan. Kategori usia muda kurang dari 39 tahun, usia sedang dengan kisaran usia 40 - 53 tahun dan usia tua dengan rentang usia 54 tahun keatas. Sasaran penyuluhan memiliki kategori usia yang beragam diantaranya enam orang atau $22 \%$ sasaran yang masuk dalam kategori muda serta merupakan usia produktif, 17 orang atau $63 \%$ sasaran termasuk dalam kategori sedang dan masih tergolong pada usia produktif serta terdapat empat orang atau $15 \%$ sasaran dalam kategori usia tua. Seseorang yang masih berusia muda dan sedang termasuk dalam usia produktif sehingga mampu menjalankan aktifitas keseharian sesuai pekerjaannya dan memilki kemauan untuk mempelajari hal-hal baru, serta dapat berinteraksi dengan masyarakat komunitas lain (Noviyanti 2017).

Undang-Undang Nomor 20 Tahun 2003 Tentang Sistem Pendidikan Nasional, mengkategorikan tingkatan pendidikan dengan tiga tingkatan diantaranya pendidikan dasar/rendah yaitu SD-SMP/MTs, pendidikan 
menengah yaitu SMA/SMK dan pendidikan tinggi yaitu D3-D4/S1. Adapun tingkat pendidikan sasaran yang termasuk dalam kategori rendah berjumlah 14 orang dengan persentase $52 \%$, kategori sedang berjumlah 6 orang dengan persentase $22 \%$ dan kategori tinggi berjumlah 7 orang dengan persentase $26 \%$. Semakin tinggi tingkat pendidikan maka semakin tinggi produktivitas dan semakin cepat daya serap akan suatu inovasi (Setiawan 2010).

Vijayanti dan Yasa (2016), menyatakan kategori pengalaman usaha dapat dibagi dalam kategori pengusaha baru dengan lama usaha kurang dari empat tahun, pengalaman usaha sedang 5 - 8 tahun dan pengusaha lama diatas 8 tahun. Sasaran penyuluhan pada penelitian ini termasuk dalam lama usaha baru berjumlah 3 orang, sedang 4 orang dan kategori lama berjumlah 3 orang sehingga dapat dikatakan jika sasaran telah memiliki pengalaman usaha yang cukup. Adapun Priyandikha (2015), menyatakan besar kecilnya pendapatan seseorang dipengaruhi oleh beberapa faktor salah satunya yaitu lama usaha serta sebagai penentu dari pendapatan, khususnya pada sektor informal.
Penyuluhan Mengenai Pemanfaatan Tulang Ikan

Hasil evaluasi awal dan evaluasi akhir pengetahuan sasaran terhadap pembuatan tepung tulang ikan terlihat perubahan peningkatan aspek pengetahuan sebanyak $49 \%$. Tingkat perubahan tertinggi diperoleh oleh sasaran atas nama Warsih dan Ernisih dengan nilai perubahan mencapai 63 . Hasil pengamatan secara observasi, perubahan ini karena tingkat keingintahuan sasaran tersebut yang tinggi, sehingga mendorongnya untuk mau berupaya dan belajar dengan serius dibandingkan dengan sasaran lainnya dalam mengikuti dan menerima setiap materi yang diberikan. Sedangkan tingkat perubahan terendah mencapai skor rata-rata 38 untuk tingkat perubahan.

Perubahan sasaran tertinggi pada aspek pengetahuan dapat diamati dari tingkat pendidikan, usia dan pengalaman sasaran. Peningkatan aspek pengetahuan dapat dipengaruhi oleh usia dan pendidikan. Semakin muda usia tingkat keingintahuan semakin tinggi dan menyebabkan tingkat perubahan semakin tinggi. Menurut Noviyanti (2017), seseorang yang masih berusia muda dan sedang termasuk dalam usia produktif sehingga mampu menjalankan aktifitas keseharian sesuai pekerjaannya dan memilki kemauan untuk mempelajari 
hal-hal baru, serta dapat berinteraksi dengan masyarakat komunitas lain.

Tingkat persetujuan akhir (post test) sasaran untuk pembuatan tepung tulang ikan adalah sebesar $86 \%$. Tingkat persetujuan meningkat sebesar $30 \%$ dari tingkat persetujuan awal yaitu $56 \%$ dilihat dari hasil tersebut maka dapat disimpulkan respon sasaran yang awalnya pada kategori ragu dapat berubah menjadi kategori sangat setuju. Sasaran adalah anggota Kelompok Bandeng C73 yang terbuka dalam merespon inovasi yang diberikan terkait pembuatan tepung tulang ikan. Hasil observasi didapatkan informasi bahwa selama ini mereka bingung bagaimana cara memanfaatkan tulang ikan. Sasaran pernah mencoba memanfaatkan tulang ikan dijadikan kerupuk tetapi gagal karena kurangnya pengetahuan. Hal ini dapat dilihat dari sikap pelaku usaha yang setuju dari setiap indikator pertanyaan yang dianjurkan. Sikap tidak akan langsung memberi respon terhadap perubahan, menyadari bahwa pengetahuan dan sikap dipengaruhi oleh pengalaman (Indraningsih 2011).

Berdasarkan Gambar 2, dapat dilihat aspek keterampilan pembuatan tepung tulang ikan pada Kelompok Bandeng C73 mengalami peningkatan dengan nilai awal $48 \%$ menjadi $88 \%$ (perubahan sebesar $40 \%$ ). Peningkatan keterampilan tertinggi ada pada responden atas nama Wacih dengan peningkatan $40 \%$. Kinerja didik dalam mendemonstrasikan keterampilannya melakukan sesuatu dapat diukur melalui teknik observasi (Subali 2014). Kegiatan aksi penyuluhan dilaksanakan dengan metode praktik secara langsung didukung adanya media lainnya seperti media cetak berupa leaflet, media tayang dan media langsung diharapkan dapat meningkatkan keterampilan dan dapat mendemonstrasikan secara mandiri materi yang telah diberikan dan dapat membuat tepung tulang ikan. Hal ini sependapat dengan pernyataan (Arsyad 2006) bahwa pengetahuan pada seseorang diterima melalui indera, paling banyak menyalurkan pengetahuan ke dalam otak adalah indera pandang kurang lebih $75 \%$ sampai $87 \%$ dari pengetahuan manusia diperoleh/disalurkan melalui indera pandang, $13 \%$ melalui indera dengar dan $12 \%$ lainnya tersalur melalui indera yang lain.

Berdasarkan data pada Gambar 3, dapat dilihat bahwa terjadi peningkatan pada tahapan adopsi, pada minggu ke 1 sasaran ada pada tahap mengetahui cara pembuatan tepung tulang ikan, pada minggu ke 4 sudah ada sasaran yang ada pada tahap implementasi adopsi pada minggu ke 7 sudah ada sasaran yang melakukan konfirmasi akan melakukan inovasi pembuatan 
tepung tulang ikan. Hal ini karena antusias sasaran dengan pembuatan tepung tulang ikan, materi diterima dengan baik dan terdapat feedback yang baik dari kegiatan aksi penyuluhan demonstrasi cara pembuatan tepung tulang ikan yang dilakukan. Keberhasilan suatu pendidikan dipengaruhi oleh strategi dan metode serta alat bantu pembelajaran yang digunakan dalam proses pendidikan, untuk itu perlu didesain secara efektif (Sedana 2012).

Berdasarkan 5 ciri inovasi dapat diterima sasaran yaitu (1) keuntungan relatif, inovasi yang diberikan mampu memberikan keuntungan bagi sasaran, terutama dalam segi ekonomi. Tulang ikan yang tidak memiliki nilai jual bagi masyarakat kini menghasilkan keuntungan sebesar Rp. 38.475.- dalam $15 \mathrm{~kg}$ tulang ikan. Kriteria seplanjutnya yaitu (2) tidak rumit, setelah bertanya secara langsung sebanyak $90 \%$ sasaran menganggap inovasi yang diberikan mudah dan tidak rumit. Kriteria lain yaitu (3) diterima/dibutuhkan, inovasi yang diberikan dapat diterima dengan baik oleh sasaran. Inovasi ini juga dibutuhkan sasaran untuk memanfaatkan limbah yang menjadi masalah bagi masyarakat. Kriteria (4) mudah dicoba, setelah melakukan beberapa sampling ke sasaran, inovasi yang diberikan itu mudah dicoba karena prosesnya tidak rumit. Kriteria (5) dapat diamati hasilnya, dalam hal ini yaitu inovasi yang diberikan dapat diamati masih berjalan hingga saat ini atau hanya sebatas tau saja dan tidak diterapkan.

Pada Tabel 3 dapat dilihat bahwa sasaran lebih banyak yang mendifusikan dibandingkan dengan yang tidak mendifusikan. Sasaran yang tidak mendifusikan setelah ditanya alasan mereka yaitu karena mempunyai pekerjaan sampingan lainnya sehingga mereka tidak bisa mendifusikan, ada juga sasaran yang tidak terlalu pandai bergaul. Penyaluran informasi terbanyak dilakukan oleh ibu Uryati karena beliau adalah ketua kelompok dan mendifusikan ke orang-orang yang datang ke kios sehingga yang datang bisa melihat dan jika bertanya/tertarik maka akan dijelaskan Ibu Uryati.

\section{Penyuluhan Demonstrasi Cara Pembuatan Kerupuk Tulang Ikan Bandeng}

Hasil evaluasi awal dan evaluasi akhir pengetahuan sasaran terhadap pembuatan kerupuk tulang ikan terlihat perubahan aspek perubahan. Terjadi peningkatan yang diperoleh dari rata-rata aspek peningkatan sebanyak $46 \%$. Tingkat perubahan tertinggi diperoleh oleh sasaran atas nama Ida dengan nilai perubahan mencapai 63. $\mathrm{Hal}$ ini dipengaruhi oleh tingkat keingintahuan yang tinggi dari sasaran tersebut, sehingga mendorongnya untuk mau 
berupaya dan belajar dengan serius dibandingkan dengan sasaran lainnya dalam mengikuti dan menerima setiap materi yang diberikan.

Hasil evaluasi aspek sikap sasaran terhadap penyuluhan dengan materi pembuatan kerupuk tulang ikan disajikan pada Tabel 4. Tingkat persetujuan akhir (Post test) sasaran untuk pembuatan tepung tulang ikan adalah sebesar $90 \%$. Tingkat persetujuan meningkat sebesar $32 \%$ dari tingkat persetujuan awal yaitu $58 \%$ dilihat dari hasil tersebut maka dapat disimpulkan respon sasaran yang awalnya pada kategori ragu dapat berubah menjadi kategori sangat setuju. Sasaran adalah anggota Kelompok Bandeng C73 yang terbuka dalam merespon inovasi yang diberikan terkait pembuatan kerupuk tulang ikan.

Aspek keterampilan pembuatan tepung tulang ikan pada kelompok bandeng c73 mengalami peningkatan dengan nilai awal $47.8 \%$ menjadi $85.6 \%$ (perubahan sebesar 37.8\%). Peningkatan keterampilan tertingi ada pada responden atas nama Uriyati dengan peningkatan 50\%. Kinerja didik dalam mendemosntrasikan keterampilannya melakukan sesuatu dapat diukur melalui teknik observasi (Subali 2014). Kegiatan aksi penyuluhan dilaksanakan dengan metode praktik secara langsung didukung adanya media lainnya seperti media cetak berupa leaflet, media tayang dan media langsung diharapkan dapat meningkatkan keterampilan dan dapat mendemonstrasikan secara mandiri materi yang telah diberikan dan dapat membuat kerupuk tulang ikan. Hal ini sependapat dengan pernyataan (Arsyad 2006) bahwa pengetahuan pada seseorang diterima melalui indera, paling banyak menyalurkan pengetahuan ke dalam otak adalah indera pandang kurang lebih $75 \%$ sampai $87 \%$ dari pengetahuan manusia diperoleh/ disalurkan melalui indera pandang, 13\% melalui indera dengar dan $12 \%$ lainnya tersalur melalui indera yang lain.

Berdasarkan data pada Gambar 6, dapat dilihat bahwa terjadi peningkatan pada tahapan adopsi, pada minggu ke 1 sasaran ada pada tahap mengetahui cara pembuatan tepung tulang ikan, pada minggu ke 4 sudah ada sasaran yang ada pada tahap implementasi adopsi pada minggu ke 6 sudah ada sasaran yang melakukan konfirmasi akan melakukan inovasi pembuatan kerupuk tulang ikan. Hal ini karena antusias sasaran dengan pembuatan tepung tulang ikan, materi diterima dengan baik dan terdapat feedback yang baik dari kegiatan aksi penyuluhan demonstrasi cara pembuatan kerupuk tulang ikan yang dilakukan. Keberhasilan suatu pendidikan dipengaruhi oleh strategi dan metode serta alat bantu 
pembelajaran yang digunakan dalam proses pendidikan, untuk itu perlu didesain secara efektif (Noviyanti 2017). Metode penyuluhan seperti demonstrasi cara, dapat menumbuhkan tingkat adopsi inovasi pada kelompok perikananan hingga 40\% (Nursahla et al. 2019).

Berdasarkan 5 ciri inovasi dapat diterima sasaran yaitu (1) keuntungan relatif, inovasi yang diberikan mampu memberikan keuntungan bagi sasaran, terutama dalam segi ekonomi. Tulang ikan yang tidak memiliki nilai jual bagi masyarakat kini menghasilkan keuntungan sebesar Rp. 60,765.- dalam $15 \mathrm{~kg}$ tulang ikan. Kriteria (2) tidak rumit, setelah bertanya secara langsung sebanyak $90 \%$ sasaran menganggap inovasi yang diberikan mudah dan tidak rumit. Kriteria (3) diterima/dibutuhkan, inovasi yang diberikan dapat diterima dengan baik oleh sasaran. Inovasi ini juga dibutuhkan sasaran untuk memanfaatkan limbah yang menjadi masalah bagi masyarakat. Kriteria (4) mudah dicoba, setelah melakukan beberapa sampling ke sasaran, inovasi yang diberikan itu mudah dicoba karena prosesnya tidak rumit. Kriteria (5) dapat diamati hasilnya, dalam hal ini yaitu inovasi yang diberikan dapat diamati masih berjalan hingga saat ini atau hanya sebatas tau saja dan tidak diterapkan.
Pada Tabel 5 dapat dilihat bahwa sasaran lebih banyak yang mendifusikan dibandingkan dengan yang tidak mendifusikan. Sasaran yang tidak mendifusikan setelah ditanya alasan mereka yaitu karena mempunyai pekerjaan sampingan lainnya sehingga mereka tidak bisa mendifusikan, ada juga sasaran yang tidak terlalu pandai bergaul. Untuk penyaluran terbanyak dilakukan oleh ibu Uryati karena beliau adalah ketua kelompok dan mendifusikan ke orang-orang yang datang ke kios sehingga yang datang bisa melihat dan jika bertanya/tertarik maka akan di jelaskan ibu Uryati.

Perubahan Perilaku Kelompok Bandeng C73 melalui Pemanfaatan Limbah Tulang Ikan

Sasaran mengalami perubahan perilaku dari awalnya sasaran membuang hasil samping pengolahan ikan bandeng, yaitu tulang ikan secara sembarangan dan sekarang sasaran sudah mulai memberikan hasil samping tersebut kepada kelompok pengolah hasil perikanan. Kelompok tersebut yaitu Bandeng C73, kelompok ini sudah di berikan penyuluhan mengenai pemanfaatan limbah tulang ikan bandeng. Perilaku sasaran mengalami perubahan pada aspek sikap yaitu $31 \%$. Dalam hal ini dapat disimpulkan bahwa sasaran mengalami perubahan perilau dari awalnya tidak sadar akan 
pentingnya menjaga lingkungan dan sekarang berubah menjadi ke tahap sadar bahkan ada yang sudah mengadopsi $40 \%$.

Pemanfaatan limbah tulang ikan bandeng bukan hanya mengubah perilaku sasaran melainkan memberi keuntungan dalam segi ekonomi dan juga lingkungan. dalam segi lingkungan sasaran bisa mengurangi dampak pencemaran lingkungan udara (bau), air (dibuang di irigasi), tanah (dibuang secara sembarangan) hal ini tentu saja dapat berpengaruh terhadap kesehatan masyarakat. Dalam segi ekonomi pemanfaatan limbah cukup menguntung kan dalam satu kali produksi pembuatan tepung tulang menghasilkan keuntungan Rp.91.000.- dan jika tepung tersebut diolah kembali menjadi kerupuk tulang ikan, stik tulang ikan atau diversifikasi olahan lainnya maka akan menghasilkan keuntungan yang lebih tinggi.

\section{SIMPULAN DAN SARAN}

Setelah diberikan penyuluhan, pemanfaatan tulang ikan bandeng dengan pembuatan tepung tulang ikan anggota kelompok Bandeng C73 mengalami peningkatan $49 \%$ pada aspek pengetahuan, perubahan pada aspek sikap mencapai $30 \%$ dan perubahan pada aspek keterampilan mencapai $40 \%$. Pada penyuluhan diversifikasi kerupuk tulang ikan anggota kelompok Bandeng C73 mengalami peningkatan $46 \%$ pada aspek pengetahuan, perubahan pada aspek sikap mencapai $32 \%$ dan perubahan pada aspek keterampilan mencapai $40 \%$. Selain itu, penyuluhan pemanfaatan tulang ikan untuk pembuatan kerupuk tulang ikan dapat merubah perilaku saran penyuluhan untuk menjaga lingkungan dan memperoleh keuntungan usaha yang lebih. Untuk memperoleh keuntungan yang lebih tinggi, pembuatan tepung tulang ikan sebaiknya dilakukan jika tulang ikan sudah terkumpul minimal 15 $\mathrm{kg}$.

\section{DAFTAR PUSTAKA}

Amdar, Anwar Akbar, Pigoselpi Anas, dan Tatty Yuniarti. 2019. "Analisis Usaha Beberapa Produk Olahan Perikanan di CV. Fania Food Kota Gede Daerah Istimewa Yogyakarta." Jurnal Penyuluhan Perikanan dan Kelautan 13(2):225-42. doi: 10.33378/jppik.v13i2.196.

Arsyad, Azhar. 2006. Media Pembelajaran. Jakarta: Raja Grafindo Persada. 
Hernawati, Ena. 2019. Kajian Potensi Perikanan di Wilayah Kecamatan Tirtajaya Kabupaten Karawang Provinsi Jawa Barat dengan Pendekatan PRA [Laporan Praktik Keahlian]. Bogor (ID).

Indraningsih, Kurnia Suci. 2011.

"Pengaruh Penyuluhan Terhadap

Keputusan Petani dalam Adopsi Inovasi Teknologi Usahatani

Terpadu." Jurnal Agro Ekonomi 29(1):1. doi:

10.21082/jae.v29n1.2011.1-24.

Mardikanto, Totok. 2009. Sistem

Penyuluhan Pertanian. Solo: Lembaga Pengembangan Pendidikan (LPP) dan UPT Penerbitan dan Pencetakan UNS (UNS Press).

Noviyanti, R. 2017. "Peran Penyuluh Bagi Nelayan Di Kelurahan Palabuhanratu Kabupaten

Sukabumi." Berkala Perikanan Terubuk 45(2):96-102. doi: 10.31258/terubuk.45.2.96-102.

Nursahla, Nursahla, Tatty Yuniarti, Herry Maryuto, dan Dedi Sutarso. 2019. "Adopsi Inovasi Probiotik pada Kolam Dempond Pendederan Ikan Mas (Cyprinus carpio) di Kelompok 'Mina Pojok Jaya' Kecamatan Subang." Jurnal Penyuluhan Perikanan dan Kelautan 13(2):121-37. doi:
Prayudi, Adham, Tatty Yuniarti, Andin Taryoto, Lilis Supenti, dan Pujoyuwono Martosuyono. 2020. "Chemical and amino acid composition of snapper scrap meat hydrolysate." $\quad A A C L \quad B i o f l u x$ 13(4):2228-41.

Priyandikha, Akhbar Nurseta. 2015. Analisis Pengaruh Jarak, Lama Usaha, Modal, dan Jam Kerja terhadap Pendapatan Pedagang Kaki Lima Konveksi (Studi Kasus di Kelurahan Purwodinatan Kota Semarang). [Skripsi]. Semarang: Universitas Diponegoro.

Purnomo, E., N. Pangarsa, K. .. Andri, dan M. Saeri. 2015. "Efektivitas Metode Penyuluhan Dalam Percepatan Transfer Teknologi Padi di Jawa Timur." Jurnal Inovasi Dan Teknologi Pembelajaran (Jinotep) 1(2):191-204.

Putra, Brilyan Handika, dan Chairul Anna. 2017. "Pengaruh Proporsi Tepung Tulang Ikan Bandeng (Chanos chanos) Terhadap Sifat Organoleptik Kerupuk Bawang." ejournal Boga 5(3):100-108.

Sedana, Gede. 2012. "Pemberdayaan Masyarakat Berdasarkan pada Kategori Adopter." dwijenAGRO 3(1). 
Setiawan, A. dan S. 2010. Pengaruh Umur, Pendidikan, Pendapatan, Pengalaman Kerja dan Jenis Kelamin terhadap Lama Mencari Kerja bagi Tenaga Kerja Terdidik di Kota Magelang. [Skripsi]. Semarang: Universitas Diponegoro.

Subali, Bambang. 2014. "Evaluasi Pembelajaran (Proses dan Produk)."
Sumbodo, Joko, Ulfah Amalia, dan Lukita Purnamayati. 2019. "Peningkatan Gizi dan Karakteristik Kerupuk Pangsit dengan Penambahan Tepung Tulang Ikan Nila (Oreochromis niloticus)." Jurnal IImu dan Teknologi Perikanan 1(1):30-36.

Vijayanti, Made Dwi, dan I. Gusti Wayan Murjana Yasa. 2016. "Pengaruh Lama Usaha dan Modal Terhadap Pendapatan dan Efisiensi Usaha Pedagang Sembako di Pasar Kumbasari." E-Jurnal Ekonomi Pembangunan 5(12):1539-66. 